УДК 636.4.082

(C) 2014

Замикула В. В., кандидат наук із держсавного управління

Інститут свинарства і агропромислового виробництва НААН

\title{
ВПЛИВ ТЕХНОЛОГІЧНИХ ПАРАМЕТРІВ ВИРОБНИЦТВА СВИНИНИ НА СТРУКТУРУ ВИРОБНИЧО-СЕЛЕКЦЙНОЇ ПІРАМІДИ
}

\author{
Рецензент - кандидат сільськогосподарських наук Л. Г. Перетятько
}

Галузь свинарства завжди потребуе посиленої уваги як виробників продукиії свинарства, служби ветеринарної медицини, так і державних структур, які контролюють стан справ $і$ надають державну підтримку виробникам продукиії у вигляді дотацій. Оскільки свинарство є зоною ризикованого тваринництва, галузь потребує розробки та впровадження новітніх технологій, засобів і прийомів, які б сприяли збільшенню багатоплідності, збереженості приплоду, підвищенню інтенсивності росту й покращання відтворювальних якостей свиноматок.

Ключові слова: свинарство, технологічні показники, виробництво свинини, багатоплідність, збереженість приплоду, продуктивність, рентабельність, прибутковість.

Постановка питання. Свинарство, як і будьяка галузь сільськогосподарського виробництва, потребує постійної уваги, поскільки зміна параметрів виробничого процесу призведе до зміни обсягів та рентабельності виробництва. Повсюдно стверджується, що свинарство обов'язково має бути дотаційним, оскільки у сучасних умовах на кормах власного виробництва досягнути рентабельного рівня неможливо. Цю тезу підтверджують посиланням на дані статистичного обліку продуктивності свиней. Так, більшість господарств Полтавської області отримують лише по 1,8-2,0 опороси за середньої багатоплідності 9-11 поросят на опорос за рівня технологічного відходу 12-13\% у підсисний період, 5$6 \%$ - у період дорощування та 1,5-2,0\% - на відгодівлі за середньодобових приростів на рівні 447 грамів. Такі показники свідчать передусім про порушення технологічних умов утримання, годівлі, відтворення, осіменіння та застосування незбалансованих раціонів.

Аналіз останніх досліджень і публікацій, у яких започатковано розв'язання проблеми. Там, де на племінних заводах створено належні умови мікроклімату, утримання й годівлі свинопоголів'я, отримують стабільні показники: 2,22,3 опоросів на рік, 12-13 життєздатних поросят на опорос, рівень збереження приплоду до реалізації становить 90-92 \%, а середньодобові прирости поросят під свиноматкою - 250-280 г, на дорощуванні - 350-400 г і на відгодівлі - 900 і більше грамів $[3,8,9]$.

У окремих племінних заводах Полтавської області, зокрема ім. Декабристів Миргородського району, було здійснено реконструкцію, наслідком якої стало можливим перевести роботу племферми 3 сезонно-турової на потокову й замість 1,7 отримати 2,2-2,3 опоросів на рік, підвищити вихід ділових поросят на одну свиноматку на 7,5 голів.

Заміна станків, за збільшення станкової площі

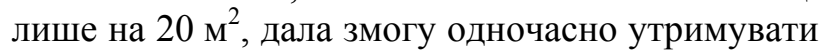
на $14 \%$ поголів'я більше, ніж за попередніх умов. Крім того це дозволило збільшити вихід ділових поросят на $1 \mathrm{~m}^{2}$ станкової площі на 6 голів, а на одного працюючого - на 660 голів. Така зміна технології дала можливість не лише зменшити кількість основних маток із 200 до 135 голів, а й додатково отримати у 4 рази більше поросят, підвищивши річний оборот станків для опоросу з 2 до 8,7 разу. Кошти, вкладені у реконструкцію приміщення та закупівлю обладнання, було повернуто вже до закінчення другого року роботи [10].

Отже, за умови спільної співпраці науковців $\mathrm{i}$ практиків, питання підвищення ефективності роботи підприємств 3 виробництва продукції свинарства можна не лише успішно вирішувати, а й отримувати рентабельну свинину.

Нижче розглянемо питання впливу рівня технологічних параметрів на прибутковість виробництва продукції свинарства та структуру виробничо-селекційної піраміди для щорічного виробництва 300 тис. голів товарного поголів'я.

Мета дослідження полягає у висвітленні впливу окремих технологічних показників на прибутковість ведення галузі свинарства та потребу в основних свиноматках для різних рівнів виробничо-селекційної піраміди.

Завдання виконаного дослідження полягає у розкритті ступеня впливу окремих технологічних показників на структуру виробничо-селекційної піраміди, потребу у кількості племінних заводів та можливість рентабельного ведення галузі свинарства на прикладі Полтавської області. 


\section{СІЛЬСЬКЕ ГОСПОДАРСТВО. ТВАРИННИЦТВО}

Матеріал і методика досліджень. Матеріалом досліджень виступали технологічні та економічні показники роботи підприємств із виробництва продукції свинарства [1, 2, 5-7].

Для проведення розрахунків було використано такі методи та прийоми: економіко-статистичний; розрахунково-конструктивний та комп'ютерного моделювання за допомогою розробленої нами програми [4].

Результати досліджень. В основу розрахунків було покладено технологічні показники, які, за даними статистичного обліку, наявні у більшості господарств Полтавської області (табл. 1).

За вищеозначених показників для функціонування виробничо-селекційної піраміди необхідно, щоб у їі структурі основних маток було у племзаводах материнської групи 3,61 \%, племзаводах першої батьківської групи - 0,04 \%, племзаводах другої батьківської групи - 0,33 \%, племінних репродукторах $-12,13 \%$ і у товарних господарствах - 83,89 відсотка.

\section{1. Вихідні технологічні показники}

\begin{tabular}{|c|c|}
\hline \multicolumn{2}{|c|}{ Технологічні показники та їх значення } \\
\hline Кількість опоросів / рік & 1,8 \\
\hline $\begin{array}{c}\text { Багатоплідність свиноматок, } \\
\text { поросят / опорос, гол. }\end{array}$ & 9,0 \\
\hline $\begin{array}{c}\text { Технологічний відхід, \% } \\
\text { у підсисний період }\end{array}$ & 13,0 \\
\hline на дорощуванні & 6,0 \\
\hline на відгодівлі & 2,0 \\
\hline $\begin{array}{c}\text { Середньодобовий приріст поросят } \\
\text { у підсисний період, г }\end{array}$ & 180 \\
\hline $\begin{array}{c}\text { Середньодобовий приріст поросят } \\
\text { на дорощуванні, г }\end{array}$ & 230 \\
\hline $\begin{array}{c}\text { Середньодобовий приріст поросят } \\
\text { на відгодівлі, г }\end{array}$ & 500 \\
\hline Незапліднених свиноматок, \% & 15 \\
\hline
\end{tabular}

Проводячи розрахунково-аналітичний пошук ступеня впливу багатоплідності свиноматок і рівня технологічного відходу на різних етапах вирощування й відгодівлі нами було здійснено п’ять послідовних розрахунків, у кожному з яких додавали по одному поросяті на опорос (табл. 2). Інтенсивність використання свиноматок залишили на рівні 1,8 опоросів на рік.

У практиці свинарства активно ведеться селекційна робота на збільшення багатоплідності свиноматок.

Так, її підвищення з 9 до 13 поросят на опорос дасть змогу збільшити річний приплід від однієї свиноматки 3 13,8 до 20,0 поросят, однак за рахунок високого рівня технологічного відходу до реалізації залишиться всього 16 поросят. За одночасного підвищення багатоплідності по всій виробничо-селекційній піраміді, призначеній для щорічного виробництва 300 тис. голів товарного поголів'я, кількість основних свиноматок можна зменшити з 27913 до 19357 голів, тобто вилучити зі всіх стад 8556 (30,6\%) голів.

За рахунок зменшення маточного поголів'я річна потреба у комбікормах зменшується 3 218,6 до 165,5 тис. тонн, тобто на 53,2 тис. тонн (24,3 відсотка).

У разі, коли інші виробничі показники залишаться на низькому (контрольному) рівні, то рентабельність виробництва, враховуючи ціни на корми, енергоносії, реалізовану племінну й товарну продукцію, все рівно залишиться мінусовою. Отже, без зміни інших технологічних показників, а лише за рахунок зміни рівня багатоплідності, неможливо отримувати рентабельну свинину.

У другій серії розрахунків планувалося встановити як за низької багатоплідності, лише підвищенням рівня збереженості приплоду, досягти значення загальновиробничих показників.

За сталих показників на рівні контрольних ми послідовно зменшували рівень технологічного відходу (розрахунок 1-3) і, лише у 4-му розрахунку, досягнувши високого рівня збереженості приплоду, збільшили рівень багатоплідності до 10 гол. на опорос (табл. 3).

Проаналізувавши отримані результати було встановлено, що у випадку низької багатоплідності свиноматок зміна лише рівня технологічного відходу також не дає бажаного результату підвищення прибутковості галузі свинарства. Зокрема, зменшення сумарного рівня технологгічного відходу з 18,5 до 15 \% (що для більшості господарств майже недосяжне) дає змогу підвищити річне збереження приплоду лише на 0,4 поросяти $(3,5 \%)$. За низького рівня використання свиноматок ( 1,8 опоросів за рік) і низького рівня середньодобових приростів прибутковість хоча й зростатиме, проте рентабельність виробництва продукції свинарства в цілому залишатиметься мінусовою. Підвищення рівня багатоплідності до 10 поросят на опорос за низького рівня інтенсивності росту також не дає бажаного результату (табл. 4). У третій серії розрахунків ми ставили за мету встановити, чи можна зробити прибутковою господарську діяльність, збільшивши лише інтенсивність використання свиноматок, а інші технологічні показники залишити на рівні контрольних. Для проведення розрахунків рівень багатоплідності й технологічного відходу залишали без змін і лише у п'ятому розрахунку змінили рівень середньодобових приростів (табл. 5). 
СІЛЬСЬКЕ ГОСПОДАРСТВО. ТВАРИННИЦТВО

\section{2. Вплив рівня багатоплідності на зміну виробничих показників}

\begin{tabular}{|c|c|c|c|c|c|}
\hline \multirow{2}{*}{ Технологічний показник } & \multicolumn{5}{|c|}{ Номер розрахунку } \\
\cline { 2 - 6 } & 1 & 2 & 3 & 4 & 5 \\
\hline $\begin{array}{c}\text { Багатоплідність свиноматок, } \\
\text { поросят/опорос, гол. }\end{array}$ & 9,0 & 10,0 & 11,0 & 12,0 & 13,0 \\
\hline Приплід на одну основну свиноматку, гол. & 13,8 & 15,4 & 16,9 & 18,4 & 20,0 \\
\hline До реалізації залишиться, гол. & 11,1 & 12,3 & 13,5 & 14,8 & 16,0 \\
\hline Разом основних свиноматок & 27913 & 25137 & 22862 & 20965 & 19357 \\
\hline Необхідно комбікорму, тонн & 218642 & 168995 & 167621 & 166471 & 165483 \\
\hline Рентабельність, \% & $-24,5$ & $-5,6$ & $-5,2$ & $-4,8$ & $-4,5$ \\
\hline
\end{tabular}

\section{3. Зміна технологічних показників (2-а серія розрахунків, вихідні дані)}

\begin{tabular}{|c|c|c|c|c|}
\hline \multirow{2}{*}{ Технологічний показник } & \multicolumn{4}{|c|}{ Номер розрахунку } \\
\cline { 2 - 5 } & 1 & 2 & 3 & 4 \\
\hline Кількість опоросів / рік & 1,8 & 1,8 & 1,8 & 1,8 \\
\hline Багатоплідність свиноматок, поросят/опорос, гол. & 9,0 & 9,0 & 9,0 & 10,0 \\
\hline Технологічний відхід під маткою, \% & 12,0 & 11,0 & 10,0 & 10,0 \\
\hline $\begin{array}{c}\text { Технологічний відхід } \\
\text { на дорощуванні, \% }\end{array}$ & 5,0 & 4,0 & 4,0 & 4,0 \\
\hline $\begin{array}{c}\text { Технологічний відхід } \\
\text { на вирощуванні (відгодівлі), \% }\end{array}$ & 1,5 & 1,0 & 1,0 & 1,0 \\
\hline $\begin{array}{c}\text { Середньодобовий приріст поросят } \\
\text { у підсисний період, г }\end{array}$ & 180 & 180 & 180 & 180 \\
\hline $\begin{array}{c}\text { Середньодобовий приріст поросят } \\
\text { на дорощуванні, г }\end{array}$ & 230 & 230 & 230 & 230 \\
\hline $\begin{array}{c}\text { Середньодобовий приріст поросят } \\
\text { на відгодівлі, г }\end{array}$ & 500 & 500 & 500 & 500 \\
\hline
\end{tabular}

\section{4. Вилив рівня технологічного відходу та багатоплідності свиноматок на зміну виробничих показників}

\begin{tabular}{|c|c|c|c|c|}
\hline \multirow{2}{*}{ Технологічний показник } & \multicolumn{4}{|c|}{ Номер розрахунку } \\
\cline { 2 - 5 } & 1 & 2 & 3 & 4 \\
\hline Приплід на 1 основну свиноматку, гол. & 13,3 & 13,3 & 13,3 & 14,8 \\
\hline До реалізації залишиться, гол. & 11,0 & 11,3 & 11,4 & 12,7 \\
\hline Разом основних свиноматок & 27171 & 26455 & 26163 & 23560 \\
\hline Необхідно комбікорму, тонн & 169523 & 168412 & 168167 & 166599 \\
\hline Рентабельність, \% & $-5,7$ & $-5,1$ & $-4,9$ & $-4,4$ \\
\hline
\end{tabular}

\section{5. Вихідні дані для розрахунку впливу інтенсивності використання свиноматок на зміну виробничих показників}

\begin{tabular}{|c|c|c|c|c|c|}
\hline \multirow{2}{*}{ Технологічний показник } & \multicolumn{5}{|c|}{ Номер розрахунку } \\
\cline { 2 - 6 } & 1 & 2 & 3 & 4 & 5 \\
\hline Кількість опоросів/ рік. & 1,8 & 1,8 & 2,0 & 2,2 & 2,2 \\
\hline Багатоплідність свиноматок, поросят/опорос, гол. & 10,0 & 11,0 & 11,0 & 11,0 & 11,0 \\
\hline Технологічний відхід під маткою, \% & 11,0 & 11,0 & 11,0 & 11,0 & 11,0 \\
\hline Технологічний відхід на дорощуванні,\% & 5,0 & 5,0 & 5,0 & 5,0 & 5,0 \\
\hline Технологічн. відхід на вирощуванні (відгодівлі), \% & 1,0 & 1,0 & 1,0 & 1,0 & 1,0 \\
\hline Середньодобовий приріст поросят у підсисний період, г & 180 & 180 & 180 & 180 & 210 \\
\hline Середньодобовий приріст поросят & 230 & 230 & 230 & 230 & 250 \\
на дорощуванні, г & & & & & \\
\hline Середньодобовий приріст поросят на відгодівлі, г & 500 & 500 & 500 & 500 & 600 \\
\hline
\end{tabular}




\section{СІЛЬСЬКЕ ГОСПОДАРСТВО. ТВАРИННИЦТВО}

За результатами розрахунків встановлено, що підвищення інтенсивності використання свиноматок, ї багатоплідності за одночасного зниження рівня технологічного відходу, відносно базових даних, призведе до збільшення виробництва продукції свинарства на основну свиноматку, але за низьких середньодобових приростів це також не дозволяє отримувати рентабельну свинину.

Лише підвищення середньодобових приростів за збереження високих показників багатоплідності свиноматок та збереженості поросят дасть можливість зменшити витрати кормів і підвищити рентабельність господарської діяльності до плюсових значень (табл. 6).

У проведених дослідженнях встановлено досить цікавий факт: підвищення лише кількості приплоду за низької інтенсивності росту призведе до збільшення видатків на високовартісні престартерні та стартерні комбікорми, що помітно підвищить собівартість свинини й позначиться на рівні рентабельності (розрахунок 4). Підвищення середньодобових приростів на всіх етапах вирощування поголів'я дозволяє зменшити тривалість періоду відгодівлі й за рахунок економії комбікорму, витрат робочого часу, енергоресурсів та збільшення обороту станко- місць підвищити рентабельність виробництва продукції свинарства (розрахунок 5).

Проведений аналіз трьох попередніх розрахунків свідчить, що підвищення лише якогось із проаналізованих вище показників дозволяє поліпшити стан справ у галузі, але не дає можливості отримувати рентабельну свинину, з огляду на високий ступінь технологічних витрат і низької окупності витраченого корму.

Враховуючи наведене вище, ми здійснили четверту серію розрахунків для моделювання вірогідності зміни прибутковості галузі свинарства за рахунок підвищення середньодобових приростів на всіх етапах вирощування молодняку свиней.

Для розрахунків ми взяли за основу реально можливі показники інтенсивності використання свиноматок, багатоплідності й технологічного відходу на різних етапах вирощування приплоду і змінювали лише інтенсивність росту молодняку (табл. 7).

Моделювання вірогідності прибуткового ведення галузі свинарства дає можливість із певним ступенем вірогідності отримати відповідь, як зміниться рентабельність господарської діяльності за умови поєднаної зміни технологічних показників (табл. 8).

\section{6. Вплив інтенсивності використання свиноматок на зміну виробничих показників}

\begin{tabular}{|c|c|c|c|c|c|}
\hline \multirow{2}{*}{ Технологічний показник } & \multicolumn{5}{|c|}{ Номер розрахунку } \\
\cline { 2 - 6 } & 1 & 2 & 3 & 4 & 5 \\
\hline Приплід на 1 основну свиноматку, гол. & 15,4 & 16,9 & 18,6 & 20,6 & 20,6 \\
\hline До реалізації залишиться, гол. & 12,9 & 14,1 & 15,6 & 17,2 & 17,2 \\
\hline Разом основних свиноматок & 24073 & 21895 & 19844 & 18005 & 18005 \\
\hline Необхідно комбікорму, тонн & 167393 & 166076 & 165321 & 166831 & 145118 \\
\hline Рентабельність, \% & $-4,8$ & $-4,4$ & $-4,3$ & $-5,3$ & 6,9 \\
\hline
\end{tabular}

7. Вихідні дані для встановлення впливу зміни рівня середньодобових приростів на виробничі показники

\begin{tabular}{|c|c|c|c|}
\hline \multirow{2}{*}{ Технологічний показник } & \multicolumn{3}{|c|}{ Номер розрахунку } \\
\cline { 2 - 4 } & 1 & 2 & 3 \\
\hline Кількість опоросів / рік & 2,2 & 2,2 & 2,2 \\
\hline Багатоплідність свиноматок, поросят/опорос, гол. & 11,0 & 11,0 & 11,0 \\
\hline Технологічний відхід під маткою, \% & 11,0 & 11,0 & 11,0 \\
\hline Технологічний відхід на дорощуванні, \% & 5,0 & 5,0 & 5,0 \\
\hline Технологічний відхід на вирощуванні (відгодівлі), \% & 1,0 & 1,0 & 1,0 \\
\hline $\begin{array}{c}\text { Середньодобовий приріст поросят } \\
\text { у підсисний період, г }\end{array}$ & 210 & 220 & 230 \\
\hline $\begin{array}{c}\text { Середньодобовий приріст поросят } \\
\text { на дорощуванні, г }\end{array}$ & 250 & 270 & 280 \\
\hline Середньодобовий приріст поросят на відгодівлі, г & 600 & 700 & 800 \\
\hline
\end{tabular}


СІЛЬСЬКЕ ГОСПОДАРСТВО. ТВАРИННИЦТВО

8. Поєднаний вплив інтенсивності використання свиноматок, багатоплідності, рівня технологічного відходу та середньодобових приростів на рентабельність виробництва свинини

\begin{tabular}{|c|c|c|c|}
\hline \multirow{2}{*}{ Технологічний показник } & \multicolumn{3}{|c|}{ Номер розрахунку } \\
\cline { 2 - 4 } & 1 & 2 & 3 \\
\hline Приплід на 1 основну свиноматку, гол. & 20,6 & 20,6 & 20,6 \\
\hline До реалізації залишиться, гол. & 17,2 & 17,2 & 17,2 \\
\hline Разом основних свиноматок & 18005 & 18005 & 18005 \\
\hline Необхідно комбікорму, тонн & 159296 & 142105 & 140399 \\
\hline Рентабельність, \% & $-1,4$ & 8,8 & 10,0 \\
\hline
\end{tabular}

9. Структура стада для виробничо-селекційної піраміди щцорічного виробництва 300 тис. голів товарного поголів'я

\begin{tabular}{|c|c|c|c|c|c|c|c|c|c|c|}
\hline \multirow{2}{*}{ Технологічний показник } & \multicolumn{7}{|c|}{ Категорії господарств } \\
\cline { 2 - 13 } & \multicolumn{2}{|c|}{ П3-1 } & \multicolumn{2}{|c|}{ П3-2 } & \multicolumn{2}{|c|}{ П3-3 } & \multicolumn{3}{|c|}{ ПР } & \multicolumn{3}{|c|}{ К(ТГ $)$} \\
\cline { 2 - 13 } & $\mathrm{H}$ & $\mathrm{B}$ & $\mathrm{H}$ & $\mathrm{B}$ & $\mathrm{H}$ & $\mathrm{B}$ & $\mathrm{H}$ & $\mathrm{B}$ & $\mathrm{H}$ & $\mathrm{B}$ \\
\hline $\begin{array}{c}\text { Кількість основних маток } \\
\text { (контроль) }\end{array}$ & 767 & 155 & 12 & 3 & 88 & 33 & 3413 & 1282 & 23633 & 15038 \\
\hline $\begin{array}{c}\text { Відсоток основних маток } \\
\text { у структрі виробничо- } \\
\text { селекційної піраміди }\end{array}$ & 3,61 & 1,25 & 0,04 & 0,02 & 0,33 & 0,21 & 12,13 & 7,75 & 83,89 & 90,77 \\
\hline $\begin{array}{c}\text { Потреба у кількості } \\
\text { господарств }\end{array}$ & 5 & 1 & 0 & 0 & 1 & 0 & 34 & 13 & 11 & 12 \\
\hline $\begin{array}{c}\text { Потреба у кількості } \\
\text { комбікорму, тис. тонн }\end{array}$ & 5,83 & 1,31 & 0,09 & 0,03 & 0,67 & 0,28 & 26,06 & 10,91 & 186,0 & 126,4 \\
\hline
\end{tabular}

П3-1 - племзаводи материнської форми (велика біла, 150 основних свиноматок);

П3-2 - племзаводи першої батьківської форми (ландрас, 100 основних свиноматок);

П3-3 - племзаводи другої батьківської форми (дюрок, 100 основних свиноматок);

ПР - племрепродуктори (велика біла, 100 основних свиноматок);

К(ТГ) - комплекси (товарні господарства) з розрахунку середньої потужності 24 тис. голів/рік;

$\mathrm{H}$ - низький рівень технологічних показників;

В - високий рівень технологічних показників.

Досягнувши рівня показників (табл. 7), рентабельність стає практично нульовою. Підвищення ж рівня середньодобових приростів дасть змогу отримувати рентабельну свинину за створення відповідних умов утримання та годівлі.

Аналіз даних вказує, що для підвищення рентабельності господарської діяльності необхідно комплексно вирішувати питання запровадження нових технологічних рішень. Підвищення лише окремих технологічних показників, без одночасного комплексного підвищення, зокрема інтенсивності використання свиноматок i їх багатоплідності, зниження рівня технологічного відходу та підвищення середньодобових приростів неможливо отримувати прибуткову продукцію свинарства. Проте вживши комплексних заходів iз налагодження системи утримання, годівлі та догляду різновікового свинопоголів'я можна навіть застосовуючи високовартісні корми отримувати рентабельну продукцію свинарства. Якщо ж водночас із покращанням рівня технологічних показників здійснити комплекс заходів, спрямованих на здешевлення використовуваних комбікормів, а саме підібрати оптимальне співвідношення між кормовими інгредієнтами, привести поживність корму у відповідність до фізіологічної потреби різновікового поголів'я тварин і замінити дороговартісні корми на більш дешеві, без втрати поживності кормової суміші, то все це дасть змогу підвищити конверсію корму та середньодобові прирости, зменшити собівартість 1 кг виробленої свинини і підвищити рентабельність господарської діяльності до 40-50 \%.

Одночасна зміна у всій виробничо-селекційній піраміді, призначеній для щорічного виробництва 300 тис. голів товарного поголів'я, значення технологічних показників із контрольного рівня (табл. 1) до підвищеного (табл. 7) дозволить зменшити необхідну кількість основних свиноматок із 27913 до 16511 голів (-11402 гол., 40,8 \%). 


\section{СІЛЬСЬКЕ ГОСПОДАРСТВО. ТВАРИННИЦТВО}

У разі здійснення означених змін для забезпечення племінною продукцією всієї виробничоселекційної піраміди необхідно мати не п'ять, а лише один племінний завод із високопродуктивними свиноматками материнської породи та в його межах (але територіально відокремлено) утримувати поголів'я тварин першої й другої батьківської породи, тому що реальна потреба у тваринах цих порід досить незначна (табл. 9).

Кількість племрепродукторів, призначених для виробництва двопородних гібридів, у разі налагодження технології, можна 3 необхідних 34 (контроль) зменшити до 13 підприємств (-21 племрепродуктор, -61,8 \%). Вивільнені 3 племінного процесу підприємства доцільніше не ліквідовувати, а перепрофілювати й на їх базі організувати добре налагоджене товарне виробництво i, використавши їх потенціал, наростити сумарні обсяги.

Запровадження нових технологічних рішень, налагодження системи утримання, годівлі та догляду за тваринами для щорічного виробництва 300 тис. голів товарного поголів'я дозволить не лише зменшити кількість основних маток, а й потребу у комбікормі з 218,6 до 140,4 тис. тонн

\section{БІБЛІОГРАФІЯ}

1. Василенко В. Н. Методика расчетов основных производственных показателей при поточной и циклично-туровой системе опоросов // В. Н. Василенко, О. Л. Третьякова, Н. В. Михайлов / Учебное пособие. - Новочеркасск, 2003. $38 \mathrm{c}$.

2. Відомчі норми технологічного проектування. Свинарські підприємства (комплекси, ферми, малі ферми): ВНТП-АПК-02.05. - К. : Мінагрополітики, 2005. - $98 \mathrm{c}$.

3. Волощук В. М. Особливості селекційно-технологічних рішень та організаційних форм у сучасно-

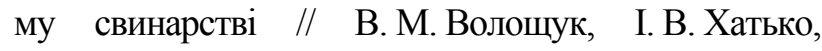
О. І. Підтереба [та ін.] / Міжвід. темат. наук. зб. «Свинарство», 2012. - Вип. 61 - С. 3-8.

4. Замикула В. В., Підтереба О. І. Смислов С. Ю. Свідоцтво про реєстрацію авторського права на твір «Комп’ютерна програма «Прогнозування економічної ефективності виробництва свинарської продукції на трипородній основі у структурі триступінчастої селекційної піраміди» від 22.08.2013 №50861.

5. Засуха Ю. В. Ефективність вирощування ремонтного і відгодівельного молодняку свиней
(-78,2 тис. тонн, $-36,8 \%$ ), що $\epsilon$ надійним резервом нарощування виробництва продукції свинарства. Зазначені зміни дадуть також можливість збільшити на одну свиноматку кількість товарного поголів'я, вирощеного до реалізації, 3 11,1 до 17,2 голів, а збиткову галузь перетворити на рентабельну.

Висновки: 1. Оскільки різні технологічні та цінові фактори по-різному впливають на прибутковість ведення галузі свинарства, їх оцінку необхідно проводити 3 урахуванням ступеня впливу.

2. Підвищення рівня багатоплідності за зменшення відсотка технологічного відходу дає відчутний результат лише за помітного підвищення рівня середньодобових приростів і здешевлення згодовуваних комбікормів.

3. Прибутковість підприємства 3 виробництва продукції свинарства визначається за комплексом ознак, які одночасно повинні сягати не нижче певного значення. Поліпшення діяльності лише окремих виробничих ланок часто призводить до невиправданого вкладання коштів і не дає очікуваного ефекту.

// Ю. В. Засуха, С. М. Грищенко, М. В. Кузьменко / Міжвід. темат. наук. зб. «Свинарство». 2012. - Вип. 60. - С. 40-45.

6. Інструкція з бонітування свиней. - К.: Видавничо-поліграфічний центр «Київський університет», 2003. - 64 c.

7. Кобилянська О. М. Ризик як економічна категорія і його особливості в аграрному виробництві // Економіка АПК. - 2008. - №1. - С. 140-145.

8. Лісний $B$. . А. Оцінка відтворювальних якостей свиноматок $з$ використанням селекційних індексів / В.А.Лісний, Т. С. Коваленко // Таврійський науковий вісник. - Херсон, 2008. Вип. 58. - Ч. 2. - С. 34-39.

9. Лимар В. О. Прогресивні технології у свинарстві та їх переваги / В. О. Лимар, В. М. Волощук, І. В. Хатько [та ін.] // Міжвід. темат. наук. зб. «Свинарство». - 2012. - Вип. 60. - С. 8-11.

10. Смислов С. Ю. Перехід від сезоннотурового вирощування племінного молодняку свиней на потокову технологію виробництва // Міжвід. темат. наук. зб. «Свинарство». - 2012. Вип. 61. - С. 9-15. 